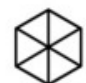 \\ LEUPHANA \\ UNIVERSITÄT LÜNEBURG
}

The (parlous) state of German unions

Schnabel, Claus; Wagner, Joachim; Addison, John T.

Publication date:

2006

Document Version

Publisher's PDF, also known as Version of record

Link to publication

Citation for pulished version (APA):

Schnabel, C., Wagner, J., \& Addison, J. T. (2006). The (parlous) state of German unions. (Working paper series in economics; No. 23). Institut für Volkswirtschaftslehre der Universität Lüneburg.

\section{General rights}

Copyright and moral rights for the publications made accessible in the public portal are retained by the authors and/or other copyright owners and it is a condition of accessing publications that users recognise and abide by the legal requirements associated with these rights.

- Users may download and print one copy of any publication from the public portal for the purpose of private study or research.

You may not further distribute the material or use it for any profit-making activity or commercial gain

- You may freely distribute the URL identifying the publication in the public portal ?

Take down policy

If you believe that this document breaches copyright please contact us providing details, and we will remove access to the work immediately and investigate your claim. 


\section{The (Parlous) State of German Unions}

John T. Addison, Claus Schnabel, and Joachim Wagner

University of Lüneburg

Working Paper Series in Economics

No. 23

February 2006

www.uni-lueneburg.de/vwl/papers

ISSN 1860 - 5508 


\title{
The (Parlous) State of German Unions
}

\author{
John T. Addison, ${ }^{*}$ Claus Schnabel, ${ }^{* *}$ and Joachim Wagner*** \\ *Department of Economics, University of South Carolina (U.S.A.), Universidade \\ de Coimbra/GEMF (Portugal), and IZA (Germany) \\ ${ }^{* *}$ Volkswirtschaftliches Institut, Friedrich-Alexander-Universität Erlangen- \\ Nürnberg (Germany) \\ *** Institut für Volkswirtschaftslehre, Universität Lüneburg, HWWA and IZA \\ (Germany)
}

February 2006

\begin{abstract}
This paper traces the profound decline in German unionism over the course of the last three decades. Today just one in five workers is a union member, and it is now moot whether this degree of penetration is consistent with a corporatist model built on encompassing unions. The decline in union membership and density is attributable to external forces that have confronted unions in many countries (such as globalization and compositional changes in the workforce) and to some specifically German considerations (such as the transition process in postcommunist Eastern Germany) and sustained intervals of classic insider behavior on the part of German unions. The 'correctives' have included mergers between unions, decentralization, and wages that are more responsive to unemployment. At issue is the success of these innovations. For instance, the trend toward decentralization in collective bargaining hinges in part on the health of that other pillar of the dual system of industrial relations, the works council. But works council coverage has also declined, leading some observers to equate decentralization with deregulation. While this conclusion is likely too radical, German unions are at the cross roads. It is argued here that if they fail to define what they stand for, are unable to increase their presence at the workplace, and continue to lack convincing strategies to deal with contemporary economic and political trends working against them, then their decline may become a rout.
\end{abstract}




\section{Introduction}

These are challenging times for German unions no less than for their counterparts in other western nations. Even though they have not been subject to debilitating legislative innovations, German unions have confronted similar economic perturbations as well as some country-specific shocks. As we shall see, they have found it very difficult to adjust to these changing economic, political, and social conditions. In consequence, union membership and density has fallen, the share of workers covered by collective agreements is down (though not yet out), there is a strong trend toward decentralization, merger activity has been defensive rather than proactive, and the occupational composition of union membership is outmoded. It is now moot whether union density fast approaching 20 percent is consistent with the corporatist model requiring encompassing unions.

In this paper, we trace the lines of a potential pathology along the dimensions of membership/density, union structure, collective bargaining, and decentralization/deregulation. But we begin with a brief statement of the institutional base of the German industrial relations system that differs substantially from Anglo-Saxon arrangements.

\section{Institutional Framework: The Dual System of Industrial Relations}

The German 'model' rests upon two pillars: centralized, industry-level collective bargaining and plant-level codetermination committees or works councils. The central wage agreements are designed to take the wage out of competition while the works councils are intended to facilitate flexible implementation of the master agreements and to represent workers' interest at the workplace. Although, as we shall see, this dual system of complementing but separate institutions is coming under increasing threat, it still applies in large part to the important 
manufacturing sector, continues to be favored by labor legislation, and remains the key institutional benchmark. Its shape thus provides a natural starting point for this essay.

Collective bargaining in Germany is based on trade unions and employers' confederations which are free to participate. With the exception of some firms (such as Volkswagen) that conclude firm-specific agreements with the unions, collective bargaining over wages and conditions (job classifications, working time and working conditions) is formally conducted outside the plant. Decisions on strikes and lockouts are similarly detached from the local level. Works councils, on the other hand, focus on production issues, handle individual grievances, and are charged with the implementation of collective agreements. They may negotiate plant agreements with local management on matters that are not covered, or not usually covered, by collective agreements. That said, they have always been involved in wage setting for two main reasons. First their extensive codetermination rights convey power which can be exercised sotto voce. Secondly, wage drift has long characterized wage determination in German manufacturing. One-size-fits-all collective agreements necessarily do not allow for individual needs (historically, those of the high fliers) and they have been accompanied by the lubricant of wage drift. Works councils have actively participated in the fixing of wages above Tarif (i.e. the formal wage schedules set under collective bargaining) and the provision of special bonuses and allowances. Nevertheless, collective bargaining agreements have always been accorded a higher status than workplace agreements, so that flexibility at the margin should not be mistaken for license.

The functions of works councils are fixed under law. According to the Works Constitution Act, works councils may be set up in all establishments with at least five permanent employees following a petition by a small group of workers or by a trade union represented at 
the establishment. Thus while mandatory they are not automatic. Works councilors are elected in secret ballot for a 4-year term, and they represent all workers not just union members. Works councils are formally independent of unions, but as a practical matter ties between the two agencies are close, with three out of five works councilors being union members. Traditionally, then, works councils have assisted in union recruitment at the place of work. Because of this they have been referred to as "pillars of union security" (Müller-Jentsch, 1995, p. 610).

The law provides the works council with far-reaching rights of information and consultation - in areas such as manpower planning, and changes in work processes, the working environment, and job content - together with an explicit set of codetermination or jointmanagement rights on so-called 'social matters.' The latter include the commencement and termination of working hours, principles of remuneration, pay arrangements including the fixing of job and bonus rates, the regulation of overtime and reduced working hours, holiday arrangements, and health and safety matters. The works council also enjoys 'consent rights' in matters of hiring and firing. Works council authority - as indexed by formal competence and size (including the number of full-time councilors) - is increasing in establishment size.

The first Works Constitution Act in 1952, which still forms much of the basis of the information, consultation, and codetermination right of the works council, is often portrayed as a 'defeat for labor' because it emphasized the independence of the works council and recognized only limited rights for unions in the plant. It also prohibited works councils from striking. The second Works Constitution Act in 1972 materially extended the information and consultation rights of the works council in respect of management decisions involving changes in capacity, working operations, and production processes, as well as strengthening codetermination rights by allowing for adjudication in the event of an impasse. Since it also improved the access of unions 
to the workplace and permitted them to submit lists of candidates in works council elections, as well as allowing works councilors to hold union office, the legislation is often hailed as a victory for labor.

The most recent changes in the law are enshrined in the 2001 Works Constitution Reform Act. The goal of this legislation was to stimulate works council formation in small- to mediumsized undertakings (by simplifying the voting procedure), to strengthen works councils (by increasing the number of full-time works councilors), and to improve the operation of the works council apparatus. In the latter exercise, cost was said to be secondary to democracy at the workplace (for details, see Addison et al., 2004). The legislation can thus be viewed as decidedly pro-labor, designed to shore up a faltering works council system (see below) and reflecting the political color of a Social Democrat-Green administration. ${ }^{1}$

That said, the economic reform program of that administration known as "Agenda 2010", and announced in March 2003, was decidedly market oriented. It was designed to reinvigorate the German economy and comprised a mix of labor market and welfare state reforms (such as changes in job protection law and in unemployment benefits). Although Agenda 2010 was fiercely opposed by organized labor and denounced by them as "socially unbalanced", the unions have not been able to stop these reforms which were upheld by the new Conservative-Social Democrat government elected in 2005. In short, union political power has not been strong enough to deflect changes that erode their bargaining power in the economic market place.

(Table 1 near here)

Before we turn to consider changes in these two pillars of the German industrial relations system, we conclude this section with some remarks on strikes. Historically, the German system has aimed at a high degree of consensus and cooperation. We have noted earlier the institutional 
means to these ends, namely, the mutually supporting but complementary agencies behind industry-wide collective bargaining and plant-level codetermination. 'Social peace' is the hallmark of the German model, and it is certainly reflected in historical strikes data. Table 1 provides some comparative information on days lost through strikes and lockouts for selected intervals since 1970 (see also Lesch, 2005). It is clear that the country has long enjoyed an enviable strike record, recording one of the lowest strike rates decade after decade. One could argue that the comparative strike record of Germany might deteriorate in the future because of the institutional erosion and changes charted below. On this reasoning, the data in Table 1 reflect the quality of Germany's industrial relations system in earlier years rather than accurately portraying status of the current, more confrontational dialogue between unions, firms and government. Alternatively put, they are an unreliable guide to the future.

\section{Union Membership and Density and Works Council Coverage}

The course of union membership since 1970 is characterized by modest growth and stagnation up to the end of the 1980s, with membership in the four main union confederations (identified in section IV) increasing by 16 percent from approximately 8.2 million to 9.6 million members. This was followed in 1991 by a rapid spurt to 13.7 million members with the absorption of almost half the members of the former East German peak organization (Freier Deutscher Gewerkschaftsbund, FDGB), ${ }^{2}$ and thence a remorseless hemorrhaging that had ratcheted back membership to 8.6 million by 2004. Since 2001 total membership of all unions in united Germany is lower than it was in West Germany before unification. These developments are graphed in Figure 1.

(Figure 1 near here) 
The corollary is declining density. Estimates based on union statistics indicate union density of about 25 percent in 2004. But these data include retirees and unemployed members. Representative data from the German general social survey (ALLBUS), relating to employees only, suggest a union density value closer to 20 percent (Schnabel and Wagner, 2005). In Table 2 we chart the course of union density from 1980 in Western Germany and from 1992 in Eastern Germany. Whereas in 1980 one in three West German employees belonged to a union, by 2004 this was true of just one in five employees. The table also shows the dramatic decline in union density in Eastern Germany in the wake of unification: down from almost 40 percent in 1992 to about 18 percent in 2004. Although only modest in the case of civil servants (Beamte), this decline in density has occurred across the board. In Western and Eastern Germany union density is lowest for white-collar workers and highest for civil servants.

(Table 2 near here)

As far as the explanations for these trends are concerned, structural/compositional factors, the transition process in Eastern Germany, and unions' own policies would all seem to figure importantly (for detailed discussions, see Fichter, 1997, Ebbinghaus, 2003, and Schnabel, 2005). First, cross-section (probit) analyses of individual membership suggest that, in addition to the direct influence of plant size, full-time workers, blue-collar workers and civil servants are more likely to join unions (Schnabel and Wagner, 2003, 2005). Given that the employment shares of full timers, blue-collar workers and civil servants has fallen in the last several decades, the decline in aggregate union density reported earlier is not surprising. ${ }^{3}$ Analysis of individuals who were never members of a union adds (from this reverse directional perspective) the positive influence of youth, education and union presence at the workplace, and the negative influence of socialization (Schnabel and Wagner, 2006). The message from these and other empirical 
inquiries is succinctly conveyed by Hassel (1999, p. 501): "German unions have remained strong in those areas where they have been traditionally strong; but are not gaining members in those areas where they have been traditionally weak." The structure of union membership harks back to an earlier employment structure that predated the rapid growth of white-collar employment and of private-sector services and the rise of non-traditional work arrangements (usually referred to as 'atypical work' in Europe). Table 3 provides evidence on the occupational structure of German unions. As can be seen, the majority of union members are still blue-collar workers whereas employment has been dominated by white-collar workers for about two decades.

(Table 3 near here)

Second, the economic dislocation and massive unemployment in Eastern Germany has played an obvious role in explaining the fall off in membership after 1991. That said, the data in Table 2 also indicate that unions were losing members among the employed population as well. In the Eastern German case, workers' disaffection with the new, transplanted unions in which they perceived themselves to be inadequately represented and integrated undoubtedly played a part.

Third, the costs of organizing the east were not without consequence for the unions either. Already buffeted by their membership losses from deindustrialization, the revenue shortfalls led unions to provide less comprehensive organizational coverage throughout the nation. The effect was to reinforce preexisting organizational deficits. Recruiting new members is hampered by the fact that there are more and more smaller workplaces and that German unions have not proved adept at organizing effective workplace organization outside of large industrial plants. ${ }^{5}$ A major dilemma of German unions is that saving costs by scaling down their regional 
and local presence and their services may result in a vicious circle of reduced benefits for members and falling membership.

The bottom line is that German unions have not been able to adjust their membership composition to structural and occupational change. In addition, macroeconomic factors, economic dislocation in the east, and union policies have also contributed to declining density. Furthermore, part of the unions' problem stems from a decline in the coverage of plant-level codetermination since works councils historically have fed trade unions with new members. As noted by Hassel (1999, p. 488), the number and coverage of works councils declined continuously during the 1980s. Other sources point to stagnation in the 1990 s and to further decline since 2000 (Kohaut and Ellguth, 2005, Table 5). In 2004, works councils were found in just one in ten German establishments in the private sector. Since their presence increases sharply with plant size, the average coverage of works councils considerably exceeds their frequency (for details, see Addison et al., 2003). Accordingly, in 2004 about 47 (38) percent of all employees in Western (Eastern) Germany worked in establishments that have a works council (in the firmament of plants with at least five employees that are allowed to set up works councils). These figures also have fallen in recent years (see Ellguth and Kohaut, 2005), so that union recruitment has become even more difficult.

\section{Union Structure}

The organizational structure of German unions has only recently undergone major change. For most of the period after the war, the dominant organizing principle of unionism in West Germany was industrial unionism, with decentralized systems of interest representation via local, district, Land and national offices. Strictly speaking, this principle only applied to the then 17 
unions representing over 80 percent of all union members that were grouped within the framework of the German Federation of Trade Unions (Deutscher Gewerkschaftsbund, DGB). Unions belonging to the two other main peak organizations, namely, the German Union of Salaried Employees (Deutsche Angestellten-Gewerkschaft, DAG) and the German Civil Service Federation (Deutscher Beamtenbund, DBB) did not conform to the industrial union principle. But all these unions can unambiguously be described as unitary unions, meaning non-partisan, and as such differentiated from their Weimar Republic counterparts which were socialist, communist, catholic, and liberal associations. ${ }^{5}$

This structure of largely industrial unionism remained in place until 1989. In that year a process of mergers and takeovers began that was to reduce the number of unions affiliated with the DGB from 17 to 8 . The process was initiated with the formation of the Media Industry Union (IG Medien) and culminated in 2001 with the creation of the almost 3 million-member strong United Services Union (Vereinte Dienstleistungsgewerkschaft, ver.di), an amalgamation of four DGB affiliates (including $I G$ Medien) and the previously independent white-collar union DAG. ${ }^{6}$

The ver.di case has received especial scrutiny. Keller (2005, p. 210) notes that the impetus came from "the decline of established industries, the rise of the private service sector, the dissolution of boundaries between plants, enterprises, and industries and privatization measures in the public sector, including the high-profile cases of railways and the post office." But the same basic impulses explain the other mergers. All were a response to losses in membership and density, and reduced dues income and bargaining power. Given that these problems continue to attach to German unions, it is realistic to assume that the merger process has not ended with the formation of ver.di. 
At issue of course is whether these essentially defensive mergers will work, stimulating membership and stemming membership decline and turning around the finances of the unions. The case of ver.di is sobering. The five constituent unions embraced different philosophies and strategies and a very heterogeneous membership. It took almost three years to complete the merger and the resulting structure is complex. It follows a 'matrix' organization, where the horizontal vector comprises multilevel regional subdivisions and the vertical vector is made up of no less 13 industry departments or sectors (see Keller, 2005, Table 2). The development of institutions and the mechanics of decision-making in the wake of the merger provide no evidence of the emergence of an integrated trade union policy for the entire services sector or of cost savings/organizational synergies - the stated goals of the merger. In other words, it is unclear whether ver.di is more than the sum of its parts. It may even be less in the event that the new structures prove more remote from the membership than were the parent unions and if diseconomies of scale and transactional failures emerge. The bald facts are that membership of the new union fell by 15 percent (to 2.53 million members) between 2000 and 2004. This diminution is greater than the corresponding fall in membership for German trade unions as a whole (12 percent) over that interval.

A final issue raised by the recent spate of union mergers in Germany is the effect on inter-union relations and the authority of the peak organization, the DGB. In the case of the formation of ver.di, interjurisdictional disputes between the former constituent unions (e.g. between the DAG and the ÖTV in the public sector) undoubtedly became easier to settle. That said, the emergence of a true multi-sector unionism may be expected to exacerbate demarcation disputes with other unions in the present milieu of declining membership and density. Finally, multi-unionism definitionally attenuates the authority of the peak organization, the DGB. 


\section{The Framework of Collective Bargaining}

Traditionally collective bargaining in Germany has been rather centralized. It still is. Negotiations are by industry and conducted at a regional level. Regional bargaining is closely coordinated by the relevant union officials and the employers association, with pilot agreements being concluded in carefully selected bargaining districts that are then transferred to other districts of the same industry or sector. There is even a measure of cross-sectoral coordination by unions and employers, which has meant an increasing uniformity in collective bargaining policy. Despite falling overall membership and density, charted in section III, high density in key sectors such as manufacturing - traditionally the wage leader - has meant that German unions are still in a position to negotiate norm-setting agreements. ${ }^{7}$

Historically, wages have advanced in line with productivity and prices, with unemployment playing a minor role (see Carruth and Schnabel, 1993). By pushing through excessive wage increases in good times and establishing downward nominal wage rigidity in bad times (on the latter, see Knoppik and Beissinger, 2003), German unions came to behave like classic insider organizations. The corollary was a sustained increase in unemployment. ${ }^{8}$ Although the past decade has witnessed the emergence of a more employment-oriented wage policy, wage policy as practiced by the two sides of industry at sectoral (and cross-sectoral) level remains solidaristic and overly prescriptive. The upshot is that there has been insufficient room for maneuver for both unsuccessful and successful employers. As a result, an undocumented numbers of employers have resigned from their employer associations or eschewed joining an employer association to begin with, while others have opted for firm-level agreements. In Eastern Germany, where the problems were more severe on labor productivity grounds, individual firms 
also reneged on the terms of agreements to which they were bound - often with the tacit agreement of the two sides at sectoral level.

This erosion of collective bargaining coverage can be observed in establishment data. Thus, in Western Germany between 1995 and 2004 the coverage rate of industry multi-employer bargaining fell from 53 to 41 percent of all establishments. The corresponding fall in coverage in Eastern Germany for almost the same interval was from 28 to 19 percent of all establishments (Kohaut and Schnabel, 2003, Ellguth and Kohaut, 2005). Also, by 2004, 2 percent of Western German and 4 percent of Eastern German establishments practiced single-employer bargaining. In addition, 40 percent of those firms in both parts of Germany that were not bound by collective agreements used sectoral agreements as a point of reference in fixing pay (and working conditions).

(Table 4 near here)

The erosion is less dramatic when we consider employee coverage. As shown in Table 4, in 200468 percent of employees in Western Germany and 53 percent of those in Eastern Germany still worked in establishments covered by either multi-employer or single-employer collective agreements. Note that coverage rises monotonically with establishment size, a finding confirmed in econometric studies (Kohaut and Schnabel, 2003). Not shown in the table, coverage rates are highest in the public sector (about 96 percent!), in mining and energy, and in banking and insurance, and they are relatively low in growing sectors such as business related services (about 43 percent) (see Ellguth and Kohaut, 2005).

With these preliminaries behind us, we next turn to the specifics of the changes in collective bargaining, which contain elements of both decentralization and deregulation. 


\section{Decentralization/Deregulation in Collective Bargaining}

The decline in coverage by collective bargaining has led the bargaining parties at sectoral level to seek to modernize the collective bargaining apparatus and devolve some authority back to the firm. Specifically, there has been a growth in works agreements negotiated between the works council and firm management. Since under the law (the Works Constitution Act) works councils cannot formally conclude works agreements on issues normally covered by collective bargaining, sectoral contracts have had to make explicit allowance for local bargaining through opening clauses. These arrangements describe the limits of plant-level regulations (for details, see Hassel, 1999, and Schnabel, 2005).

The first opening clauses applied to working time. Thus, in 1984 the metal sector industry agreement not only allowed for the exemption of certain workers from the contractually-agreed reduction in the working week but also permitted plant bargaining on the distribution of working time. This has led to an increasingly flexible use working time at establishment level to suit order books; for example, individual working time can vary in a certain corridor without the activation of overtime premia. A decade later, the metal sector agreement made provision for individual companies to cut the length of the normal working week of employees without compensation to safeguard employment. Over the years, then, working time arrangements at plant-level have become increasingly flexible.

More recently, opening clauses have also applied to wages and salaries, although in most cases the collective bargaining parties (at sector level) retain the right to veto works agreements. In 1997, for example, the sectoral contract in the chemical and rubber industry in Western Germany introduced one such opening clause - with veto rights - allowing companies to reduce the collectively agreed wage by up to 10 percent for a limited period of time so as to save jobs 
and/or improve their competitiveness. This contract innovation was stimulated by threats from several companies to quit the employers association. Note that opening clauses are activated by joint agreement - a works agreement - between works council and local management, and neither side can resort to strikes/lockouts in the negotiating process.

'Hardship agreements' in Eastern German manufacturing are perhaps better known. Such clauses enable companies to be exempted from the relevant sectoral agreement for a period of time. Companies seeking this route have to prove that they are close to bankruptcy and demonstrate a strategy for economic recovery (i.e. open their books to scrutiny). More commonly, however, Eastern German companies covered by an industry agreement have simply paid lower wages than specified under the contract after informal agreements with their workforces, quite often as we have noted with the tacit agreement of the bargaining parties.

Also, most large companies in both parts of Germany have signed so-called alliances for jobs with their workforces. Such agreements generally contain a number of measures designed to increase competitiveness and secure jobs. Examples include increased flexibility in the use of working time and limitations on pay increases in exchange for employment guarantees (see Rehder, 2003).

There is thus a considerable amount of decentralization being introduced force majeure into the German system of collective bargaining. Much of it focuses on the works council entity, which as we have seen already possesses sizeable authority under the German dual system of industrial relations. Moreover, although works councils can restrict management authority, slow down decision making, and reduce profitability (for a review of their effects on firm performance, see Addison, Schnabel, and Wagner, 2004b), they have increasingly gained acceptance from employers. The reason is that, while typically cut from the union cloth, works 
councilors are often more pragmatic and flexible than their political and ideological trade union parents, supporting rationalization if the economic position of the establishment can be improved thereby and layoffs avoided (and even where not in recent years). The heightened pace of technological and organizational change has elevated the relevance of the workplace, increased the importance of cooperation, and increasingly drawn works councils into codetermining certain strategic decisions.

If the enhanced role of the works council is not a problem for trade unions, jealous of their own powers, then the decline of the works council, noted in section III, most emphatically is. As we have seen, the industrial relations system has not been able to project its institutions beyond manufacturing industries into the growing sectors of private services and high technology. As a result, in the private sector just about 40 percent of employees in Western Germany and 30 percent of employees in Eastern Germany are today covered by both a binding collective agreement and a works council (Ellguth and Kohaut, 2005). Since works councils have historically supervised the implementation of collective agreements, their erosion means that unions will be less able to perform their regulative and distributional function.

In this light some observers have concluded that decentralization amounts to deregulation. Thus, Hassel (1999, p. 499-500) has noted examples among medium-sized firms where management has asked the workforce to openly violate existing collective agreements. Also noting that wage concessions within existing collective agreements have typically taken the form of reductions in or removal of special bonuses by large companies (e.g. Opel, Ford, and Bayer), she argues that such wage shading places smaller companies at a disadvantage. Not having voluntary pay bonuses, the easiest way for such firms to restore their relative economic position may be to exit the collective bargaining system altogether. On this view, externalities 
contribute to a downward spiral of decentralization pressures and institutional erosion, which may result in further reductions of both bargaining coverage and union density in the near future.

\section{A Summing Up}

German unions are in parlous state. Union density among employees has fallen from 33 percent in 1980 to about 20 percent today, and the decline has not yet been arrested. The reduction in union membership has not merely damaged union bargaining power in the economic market place but also in the political market place, where unions proved unable to reverse the economic reform agenda of a Social-democratic-Green administration and now must confront a coalition government less favorably disposed toward them.

Their decline is an admixture of external and internal factors. Among the former are compositional changes in the workforce. Among the latter are the unions' own structures and policies (marked in the case of $I G$ Metall by internal divisions in the leadership and actions rendolent of the class struggle). The outcome of declining membership is falling dues income, which in turn impairs organizational revitalization. One response has been merger activity, but in Germany as in other nations there are few signs that defensive mergers have been able to revivify unionism. Organizational withdrawal from low membership areas and the loss of face-to-face contact are the stuff of further decline. Recent attempts by some unions to negotiate special wage benefits and employment security clauses that apply exclusively to their members and may not be extended by employers to non-members - as well as strike action in 2006 against the relocation of plants to (less costly) production sites in Eastern Europe and against a lengthening of the working week in the public sector - can be interpreted as attempts to win new members. In general, however, the unions have failed to identify promising and successful strategies for 
attracting younger workers, women, and increasingly heterogeneous other groups of employees. Although this problem is not confined to German unions, it intrudes further upon their grief.

Along with declining membership, there has occurred a decentralization of collective bargaining and a marked decline in the number of workers covered by a collective agreement. Thus far, multi-employer bargaining dominates single-employer bargaining - although the latter has grown rapidly in recent years - so that decentralization has mainly taken place within the existing structure of collective bargaining. That is, the loss in membership in unions and employer associations has prompted the two sides, or 'social partners' as they are still known, to grant firms more flexibility in the form of opening clauses geared initially to hours of work and latterly to wages. There is no suggestion that the needs of companies for flexibility have grown less, so that the system will have to accommodate further flexibility if it is to retain influence. In recognition of this, in December 2003, the mediation committee of the two chambers of the German parliament adopted a joint declaration requesting the trade unions and employer associations to agree to more opening clauses within sectoral collective agreements.

At issue is whether the unions and employer associations can sufficiently modernize and decentralize the German system of collective bargaining in a planned manner. One problem is that the agency of workplace representation, the works council, has also been subject to erosion. Comparatively few establishments are covered both by collective bargaining and works councils. This places limits on what can be achieved through planned decentralization, leading some observers to equate decentralization with deregulation. Instead of including opening clauses into sectoral collective agreements, unions could try to directly negotiate firm-level contracts, and in the process win (or force) back firms that have left employer associations. Decentralized bargaining, however, would substantially increase transaction costs for the unions and might 
only be worth the effort in larger companies. No matter which road is taken, it seems unlikely that German collective bargaining will decentralize on Anglo-Saxon lines.

In sum, although it is much too early to write the obituary for trade unions in Germany, the traditional German model of industrial relations is actively at risk. That model is based on encompassing interest associations, codetermination, and (sectoral) collective agreements. Each element is experiencing erosion. Today only in (a subset of) manufacturing and in the public sector do we find substantial and stable union density, high collective bargaining coverage, and high works council frequency. In other branches, and most especially in the growing part of the economy (private services), we observe a shrinking base. The constellation of collective bargaining arrangements that will emerge will depend on the speed of learning of the unions.

Not only in industrial and labor relations but also in the political arena, German unions face difficult decisions; in particular, whether to behave more pragmatically and try to influence reforms or to strictly oppose them for ideological reasons. It does not help matters that the views/strategies of individual unions range from "social partnership" (as successfully implemented by the chemical and energy union $I G B C E$ ) to "countervailing power" against employers and government alike (as proposed and followed by the two biggest unions, IG Metall and ver.di). If the German unions do not soon define what they stand for in the twenty-first century, if they do not increase their presence at the workplace, and if they do not come up with convincing strategies for coping with the various economic and political trends working against them, they are on the road to oblivion. 


\section{Footnotes}

1. In this treatment, we do not emphasize codetermination at the enterprise level or, crudely put, worker directors. Under the 1951 Codetermination Act workers in the coal, iron, and steel industries were granted full-parity representation on their company supervisory boards. Subsequently, under the highly controversial 1976 Codetermination Act, quasi-parity board representation was extended to the generality of workers in firms with more than 2,000 employees. In the interstices, the 1952 Works Constitution Act, referred to earlier, had given one-third supervisory board representation to workers in firms employing more than 500 workers (for an analysis of the effects on shareholder wealth of this type of board level representation, see Gorton and Schmid, 2004).

2. Space constraints rule out consideration of 15 East German trade unions and this umbrella organization (the Confederation of Free German Trade Unions). Suffice it to say that as organs of the communist state they lacked the standard collective bargaining functions as well as the right to withdraw labor in furtherance of union goals.

3. In a panel analysis, Beck and Fitzenberger (2004) find that at the individual level the propensity to be a union member has not changed considerably over time, so that the aggregate decline in membership is mainly due to composition effects. For an analysis that points to the role of industry-specific net union densities/social custom as a factor influencing individual membership, see Goerke and Pannenberg (2004).

4. For an interesting study of union shop floor representation, see Klikauer (2004).

5. One exception to unitary unionism is the comparatively small Confederation of Christian Unions (Christlicher Gewerkschaftsbund, CGB), while other exceptions to industrial unionism are the special organizations serving executives, airline pilots, and hospital doctors, inter al. Note, however, that even within the DGB two member unions - the Metalworkers' Union (IG Metall) and the former Public Services, Transport and Communication Union (Gewerkschaft Öffentliche Dienste, Transport und Verkehr, ÖTV) might be described as multiple industry unions from the outset.

6. The four DGB affiliates in order of size were the Public Services, Transport and Communication Union (ÖTV), the German Postal Workers Union (Deutsche Postgewerkschaft, DPG), the Commerce, Banking and Insurance Union (Gewerkschaft Handel, Banken und 
Vesicherungen, HBV), and the Media Industry Union (IG Medien). For further details on the mergers, see Keller (2005).

7. For an interesting cet. par. analysis of the effect of coverage by a collective agreement on wages in Lower Saxony, using linked employer-employee data for the years 1990, 1995, and 2001, see Stephan and Gerlach (2005). They estimate the average wage gain of working under a sectoral collective contract at 4 percent in 1990 rising to 12 percent in 2001.

8. Employment effects have been exacerbated by another union bargaining preoccupation: the successful drive for a phased reduction in the working week, spearheaded by IG Metall. In 2003, however, this union had to call off a four-week strike meant to force East German metal-working employers to lower the working week to 35 hours. More and more employers are demanding a return to the 40-hour working week, and in recent years quite a few firms have managed to push through longer working time without extra pay for the employees involved by threatening to move production units and jobs abroad. 


\section{References}

Addison, John T., Claus Schnabel, and Joachim Wagner. 2004. "The Course of Research into the Economic Consequences of German Works Councils." British Journal of Industrial Relations 42 (June): 255-281.

Addison, John T., Lutz Bellmann, Claus Schnabel, and Joachim Wagner. 2003. "German Works Councils Old and New: Incidence, Coverage, and Determinants." Schmollers Jahrbuch 123 (3): 339-358.

Addison, John T., Lutz Bellmann, Claus Schnabel, and Joachim Wagner. 2004. "The Reform of the German Works Constitution Act: A Critical Appraisal.” Industrial Relations 43 (April): 392420 .

Beck, Martin and Bernd Fitzenberger. 2004. "Changes in Union Membership Over Time: A Panel Analysis for West Germany.” Labour 18 (3), 329-362.

Carruth, Alan and Claus Schnabel. 1993. "The Determination of Contract Wages in West Germany." Scandinavian Journal of Economics 95 (3): 297-310.

Ebbinghaus, Bernhard. 2003. "Die Mitgliederentwicklung deutscher Gewerkschaften im historischen und internationalen Vergleich." In Wolfgang Schroeder and Bernhard Wessels, eds., Die Gewerkschaften in Politik und Gesellschaft der Bundesrepublik Deutschland. Wiesbaden: Westdeutscher Verlag, pp. 174-203

Ellguth Peter and Susanne Kohaut. 2005. "Tarifbindung und betriebliche Interessenvertretung: Aktuelle Ergebnisse aus dem IAB-Betriebspanel.” WSI Mitteilungen 58 (July): 398-403.

Fichter, Michael. 1997. "Trade Union Members: A Vanishing Species in Post-Unification Germany. German Studies Review 20 (February): 83-104.

Goerke, Laszlo and Markus Pannenberg. 2004. "Norm-Based Trade Union Membership: Evidence for Germany." German Economic Review 5 (November): 481-504.

Gorton, Gary and Frank A. Schmid. 2004. "Capital, Labor, and the Firm: A Study of German Co-determination." Journal of the European Economic Association 2 (September): 863-905.

Hassel, Anke. 1999. "The Erosion of the German System of Industrial Relations." British Journal of Industrial Relations 37 (September): 483-505.

Keller, Berndt. 2005. "Union Formation through Merger: The Case of Ver.di in Germany." British Journal of Industrial Relations 43 (June): 209-232.

Klikauer, Thomas. 2004. "Trade Union Shopfloor Representation in Germany." Industrial Relations Journal 35 (January): 2-18.

Knoppik, Christoph and Thomas Beissinger. 2003. "How Rigid are Nominal Wages? Evidence and Implications for Germany.” Scandinavian Journal of Economics 105 (4), 619-641. 
Kohaut, Susanne and Claus Schnabel. 2003. "Zur Erosion des Flächentarifvertrags: Ausmaß, Einflussfaktoren und Gegenmaßnahmen." Industrielle Beziehungen 10: 193-219.

Lesch, Hagen. 2005. "International Comparison of Labor Disputes and Structural Change." CESifo Forum 6 (Winter): 42-52.

Müller-Jentsch, Walter. 1995. "Germany: From Collective Voice to Co-Management.” In Joel Rogers and Wolfgang Streeck, eds., Works Councils - Consultation, Representation and Cooperation in Industrial Relations. Chicago, IL: Chicago University Press, pp. 53-78.

Rehder, Britta. 2003. Betriebliche Bündnisse für Arbeit in Deutschland. Frankfurt: Campus Verlag.

Schnabel, Claus. 2005. "Trade Unions in Germany: On the Road to Perdition?" In Susan Fernie and David Metcalf, eds., Trade Unions: Resurgence or Demise? London and New York: Routledge, pp. 213-230.

Schnabel, Claus and Joachim Wagner. 2003. "Trade Union Membership in Eastern and Western Germany: Convergence or Divergence?” Applied Economics Quarterly 49 (3): 213-232.

Schnabel, Claus and Joachim Wagner. 2005. Determinants of Trade Union membership in West Germany: Evidence from Micro Data, 1980-200.” Socio-Economic Review 3 (January): 1-24

Schnabel, Claus and Joachim Wagner. 2006. "Who Are the Workers Who Never Joined a Union? Empirical Evidence from Western and Eastern Germany." Industrielle Beziehungen 13 (in press).

Stephan, Gesine and Knut Gerlach. 2005. "Wage Settlements and Wage Setting: Results from a Multi-Level Model." Applied Economics 37 (November): 2297-2306. 
Figure 1: Trade Union Membership in Germany

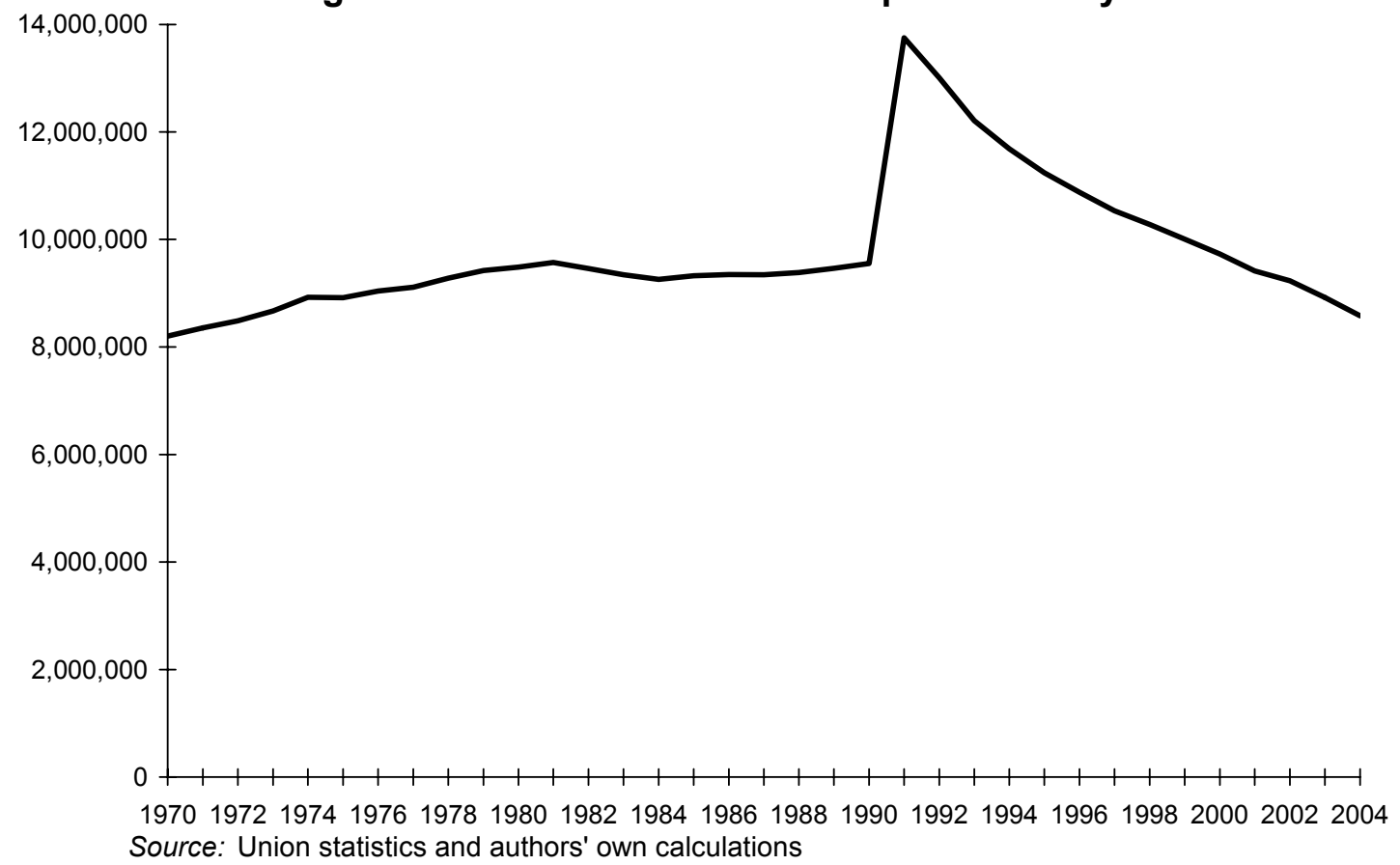


Table 1: Working Days Lost through Strikes and Lockouts, 1970-2003, Selected Countries (per thousand employees in employment; yearly averages)

Country 1970-1979 1980-1989 1990-1999 2000-2003

\begin{tabular}{lrrrr} 
A & 11 & 2 & 4 & 100 \\
B & 275 & - & 34 & $42^{1}$ \\
$\mathrm{D}^{2}$ & 52 & 27 & 11 & 4 \\
DK & 261 & 178 & 168 & 44 \\
E & 792 & 640 & 311 & 221 \\
F & 286 & 119 & 77 & $103^{3}$ \\
FIN & 613 & 408 & 168 & 56 \\
I & 1511 & 623 & 158 & 140 \\
IRL & 758 & 380 & 119 & 49 \\
NL & 40 & 15 & 22 & $14^{1}$ \\
P & - & 149 & 36 & 18 \\
S & 46 & 182 & 50 & 42 \\
U.K. & 569 & 334 & 29 & 29 \\
CH & 2 & 0 & 2 & 4 \\
N & 45 & 99 & 81 & 78 \\
AUS & 634 & 351 & 123 & 50 \\
CDN & 882 & 520 & 219 & 157 \\
J & 124 & 10 & 2 & 0 \\
U.S.A. & 507 & 123 & 40 & 52 \\
\hline
\end{tabular}

Notes: ${ }^{1} 2000-2002$ only.

${ }^{2}$ Until and including 1990 the data pertain to West Germany.

${ }^{3} 2000-2001$ only.

Sources: Institut der deutschen Wirtschaft Köln based on ILO, OECD, Eurostat, and national statistics 
Table 2: Union Density in Western and Eastern Germany, Selected Years (in percent)

\begin{tabular}{|c|c|c|c|c|c|c|c|c|c|c|c|}
\hline \multirow[t]{2}{*}{ Year } & \multirow{2}{*}{$\begin{array}{l}1980 \\
\text { West }\end{array}$} & \multirow{2}{*}{$\begin{array}{l}1984 \\
\text { West }\end{array}$} & \multirow{2}{*}{$\begin{array}{l}1988 \\
\text { West }\end{array}$} & \multicolumn{2}{|c|}{1992} & \multicolumn{2}{|c|}{1996} & \multicolumn{2}{|c|}{2000} & \multicolumn{2}{|c|}{2004} \\
\hline & & & & West & East & West & East & West & East & West & East \\
\hline All & 32.7 & 31.6 & 29.4 & 28.7 & 39.7 & 26.6 & 26.7 & 25.4 & 18.5 & 21.7 & 18.3 \\
\hline Male & 39.6 & 38.7 & 37.5 & 36.0 & 35.8 & 33.8 & 28.8 & 31.0 & 20.8 & 26.3 & 16.8 \\
\hline Female & 20.3 & 19.0 & 16.9 & 18.5 & 43.5 & 16.3 & 24.1 & 17.7 & 16.1 & 15.8 & 20.0 \\
\hline Blue collar & 36.3 & 38.1 & 36.9 & 37.6 & 37.8 & 38.3 & 28.0 & 31.6 & 22.2 & 29.6 & 19.6 \\
\hline White collar & 26.3 & 20.1 & 22.1 & 20.2 & 40.7 & 16.2 & 24.2 & 18.5 & 15.1 & 13.8 & 17.7 \\
\hline Civil servants & 45.2 & 52.2 & 41.7 & 43.5 & 50.0 & 44.7 & 53.3 & 37.1 & 31.3 & 42.0 & n.a. \\
\hline
\end{tabular}

Source: Schnabel and Wagner $(2003,2005)$ based on ALLBUS data 
Table 3: Occupational Composition of the German Labor Movement (percentage of union members belonging to certain occupational groups)

\begin{tabular}{lccc}
\hline & 1981 & 1990 & 2002 \\
\hline Blue-collar workers & 58.0 & 56.9 & 51.1 \\
White-collar workers & 24.2 & 26.4 & 32.5 \\
Civil servants & 16.7 & 17.8 & 16.5 \\
\hline
\end{tabular}

Note: Figures for 1980 and 1990 refer to West Germany.

Source: Authors' own calculations from union statistics. 
Table 4: Collective Bargaining Coverage in Western and Eastern Germany in 2004 (percentage of establishments [and employees] covered)

\begin{tabular}{|c|c|c|c|c|c|c|}
\hline \multirow[t]{2}{*}{$\begin{array}{l}\text { Establishment size } \\
\text { interval (number } \\
\text { of employees) }\end{array}$} & \multicolumn{2}{|c|}{$\begin{array}{l}\text { Multi-employer } \\
\text { sectoral collective } \\
\text { agreement }\end{array}$} & \multicolumn{2}{|c|}{$\begin{array}{l}\text { Single-employer } \\
\text { collective } \\
\text { agreement }\end{array}$} & \multicolumn{2}{|c|}{$\begin{array}{l}\text { No collective agreement } \\
\text { (in brackets: share of firms } \\
\text { using sectoral agreement } \\
\text { as a point of reference) }\end{array}$} \\
\hline & West & East & West & East & West & East \\
\hline 1 to 9 & 36 & 15 & 2 & 3 & $63\{36\}$ & $82\{39\}$ \\
\hline 10 to 49 & 53 & 31 & 3 & 7 & $44\{53\}$ & $62\{48\}$ \\
\hline 50 to 199 & 59 & 45 & 8 & 16 & $33\{53\}$ & $39\{49\}$ \\
\hline 200 to 499 & 70 & 57 & 11 & 19 & $20\{59\}$ & $25\{57\}$ \\
\hline 500 and above & 81 & 65 & 12 & 20 & $8\{52\}$ & $15\{47\}$ \\
\hline All establishments & 41 & 19 & 2 & 4 & $57\{40\}$ & $77\{40\}$ \\
\hline All employees & 61 & 41 & 7 & 12 & $32\{50\}$ & $48\{47\}$ \\
\hline
\end{tabular}

Source: IAB Establishment Panel (Ellguth and Kohaut, 2005) 


\section{Working Paper Series in Economics}

(see www.uni-lueneburg.de/vwl/papers for a complete list)

No. 1: Joachim Wagner: Nascent and Infant Entrepreneurs in Germany. Evidence from the Regional Entrepreneurship Monitor (REM), March 2005

No. 2: Ingrid Ott and Stephen J. Turnovsky: Excludable and Non-Excludable Public Inputs: Consequences for Economic Growth, June 2005 (Revised version) (also published as CESifo Working Paper 1423)

No. 3: $\quad$ Thomas Wein and Reimund Schwarze: Is the Market Classification of Risk Always Efficient? - Evidence from German Third Party Motor Insurance, March 2005

No. 4: Joachim Wagner: Exports and Productivity: A Survey of the Evidence from Firm Level Data, March 2005

No. 5: Christiane Clemens and Maik Heinemann: Endogenous Redistributive Cycles - An overlapping Generations Approach to Social Conflict and Cyclical Growth, March 2005

No. 6: Christiane Clemens and Maik Heinemann: On the Effects of Redistribution on Growth and Entrpreneurial Risk-Taking, March 2005

No. 7: Thomas Wein: Associations' Agreement and the Interest of the Network Suppliers - The Strategic Use of Structural Features, March 2005

No. 8: Joachim Wagner: Exports, Foreign Direct Investment, and Productivity: Evidence from German Firm Level Data, March 2005

No. 9: Gabriel Desgranges and Maik Heinemann: Strongly Rational Expectations Equilibria with Endogenous Acquisition of Information, March 2005

No.10: Joachim Wagner: Der Noth gehorchend, nicht dem eignen Trieb. Nascent Necessity and Opportunity Entrepreneurs in Germany. Evidence from the Regional Entrepreneurship Monitor (REM), May 2005

No.11: Joachim Wagner: Exporte und Produktivität in mittelständischen Betrieben Befunde aus der niedersächsischen Industrie (1995 - 2004), June 2005

No.12: Claus Schnabel and Joachim Wagner: Who are the workers who never joined a union? Empirical evidence from Germany, July 2005

No.13: Lena Koller, Claus Schnabel und Joachim Wagner: Arbeitsrechtliche Schwellenwerte und betriebliche Arbeitsplatzdynamik: Eine empirische Untersuchung am Beispiel des Schwerbehindertengesetzes, August 2005

No.14: Joachim Wagner: German Works Councils and Productivity: First Evidence from a Nonparametric Test, September 2005

No.15: Joachim Wagner: Firmenalter und Firmenperformance Empirische Befunde zu Unterschieden zwischen jungen und alten Firmen in Deutschland, September 2005

No.16: Joachim Wagner: Politikrelevante Folgerungen aus Analysen mit wirtschaftsstatistischen Einzeldaten der Amtlichen Statistik, Februar 2006

No.17: Wiebke B. Röber und Thomas Wein: Mehr Wettbewerb im Handwerk durch die Handwerksreform?, Februar 2006

No.18: Thomas Wein und Wiebke B. Röber: Handwerksreform 2004 - Rückwirkungen auf das Ausbildungsverhalten Lüneburger Handwerksbetriebe?, Februar 2006 
No.19: Jan Kranich und Ingrid Ott: Geographische Restrukturierung internationaler Wertschöpfungsketten - Standortentscheidungen von KMU aus regionalökonomischer Perspektive, Februar 2006

No.20: [in Arbeit]

No.21: Corinna Bunk: Betriebliche Mitbestimmung vier Jahre nach der Reform des BetrVG: Ergebnisse der 2. Befragung der Mitglieder des Arbeitgeberverbandes Lüneburg Nordostniedersachsen, Februar 2006

No.22: Joachim Wagner, Thorsten Schank, Claus Schnabel, and John T. Addison: Works Councils, Labor Productivity and Plant Heterogeneity: First Evidence from Quantile Regressions, February 2006

No.23: John T. Addison, Claus Schnabel, and Joachim Wagner: The (Parlous) State of German Unions, February 2006 
Universität Lüneburg

Institut für Volkswirtschaftslehre

Postfach 2440

D-21314 Lüneburg

Tel: ++4941316772321

email: brodt@uni-lueneburg.de

www.uni-lueneburg.de/vwl/papers 